\title{
Guiding adults: Researching the ANT-ics of confessing
}

Robin Usher Richard Edwards

In this chapter, we begin with a confession. This work is derived from our existing publications over a twenty year period on Foucault's notion of confession and its enactments within the education of adults (Edwards and Usher 1995, Usher and Edwards 1998, 2004, 2007). In this chapter, we draw selectively upon Actor-Network Theory (ANT) to enhance and extend our use of Foucault's later work to develop our understanding of the significance of guidance work with adults in education and how we might research that empirically. We suggest that approaches adopted from ANT provide a useful trajectory through which to provide more effectively a theoretical and methodological basis for the empirical study of confessional practices.

While aspects of ANT has become influential in research in education in recent years as part of wider interests in sociomaterialism (see Fenwick and Edwards 2010), it has received little attention in the realms of guidance or the wider study of confessional practices. What we wish to do in this chapter is to explore the ways in which a particular type of human subject is centred and stabilised through the humanistic discourses of guidance, but to do so without ourselves drawing on humanistic discourse. We also wish to outline ways in which this could be explored empirically. In order to do this, we will briefly reprise some of our previous work on Foucuault's framing of confession and pastoral power. However, we will suggest also that 
Foucualt's work is suggestive rather than empirically substantive. We will then discuss the ways in which aspects of ANT can be used to extend empirically our understanding of confessional practices in the formation of subjects through guidance. The aim is to provide a stronger empirical base through which to enhance our understanding of the work that certain practices of guidance do and, in this way, to think guidance differently as forms of confession associated with particular framings of subjectivity and power. We will also be suggesting that, while confession may be taken up as a totalising concept with data being retro-fitted to the concept, the empirical study of confessional enactments is likely to indicate confession's multiplicity in the exercises of certain forms of power in the ordering of the social and the need to extend and develop our understanding of the concept beyond that put forward by Foucault (1981).

\section{The humanist subject - origin/effect?}

While there are different strands in the discourses of guidance in education, there is a certain commonality in the assumption that these practices, as well as being more efficient in matching educational opportunities and adult choice, are also more progressive. While there is a more market oriented focus to some guidance discourses, it is suggested more commonly that they provide a more 'humane', 'democratic' and 'empowering' contribution to educational experiences. They are said to be part of more student-centred approaches, unlike more traditional transmission and authoritarian modes of educational provision. The argument is that the more the individual is given the opportunity to engage in understanding themselves, their capabilities and the choices available to them and to make their own more 'authentic' choices, the more power they accrue. The result is a greater degree of personal development, self-actualisation and 
empowerment through the educational experience. Guidance develops self-knowledge and knowledge of educational opportunities, enabling better interactions and outcomes.

The basis for this discursive construction is the humanistic psychology most commonly associated with Carl Rogers (see for example 1961, 1980 and 1983). Here therapeutic notions of the importance of feelings to the authentic all round development and expression of self are translated into educational discourses and practices where selfdevelopment and self-realisation become framed as central normative goals for individuals and educational institutions, embracing the affective as well as the cognitive and rational selves. Individual experiences and feelings are inserted into educational processes and become the means by which rationality, skills and attitudes are developed more fully. Thus, it is the whole person rather than simply the intellectual 'head' and/or psychomotor 'hands' that engages in and is affected by the educational processes. This discourse, framed within the psychotherapeutic, has had a very powerful effect, not only in influencing liberal education, but also in the fields of training, vocational education and human resource development. Its ubiquity has led some to argue more critically that contemporary forms of social order are therapeutic in a negative sense, promoting victimhood rather than empowerment in populations (e.g. Ecclestone and Hayes 2009, Wright 2010). The humanistic discourses of guidance can be seen therefore as playing a very important role in the contemporary structuring of educational opportunities for adults. Under the influence of these discourses, and setting aside the critiques, it would appear that both guidance and education more generally have become more humane. This is suggested as emerging from putting adults at the centre of the process, as the origin from which their development is supported through guidance and the provision of appropriate educational opportunities. 
However, our argument, following Foucault, is that the human subject is precisely centred as such through such humanistic practices; the subject is an effect within a network of relations rather than a point of origin from which all else unfolds. This is a position pursued in great detail in the works of researchers such as Rose $(1991,1998,1999)$. We argue therefore that, even if the discourses and practices of guidance have become ever more humane, it does not necessarily follow that power in modern society is more extensively distributed or that its exercise is becoming less pervasive, let alone that humanistic subjectivities are freed from its influence. On the contrary, more human(e) does not equate with the diminution of regulatory power. It may lead to more, albeit different forms of, regulatory power. However, unlike those who argue that this simply produces therapeutic victimhood, we have previosuly argued, like Foucault, that there are active subjectivities being formed through such processes (Edwards and Usher 1995). To be(come) human is itself therefore a manifestation of exercises of certain forms of power. In particular, these are subjectivities associated with the exercise of pastoral power, and with practices of confession, to which we now turn.

\section{Confession}

The discussion of confession is very much tied into Foucuault's (1981) study of sexuality. It is also linked to his wider discussion of the different forms of power developing with the emergence of modern state and institutional forms of governing (Foucualt 1979a, 1979b). We will focus primarily on the link to his work on sexuality.

Rejecting the popular view of the 19th century as a period of sexual repression where it is suggested that speaking of sex was taboo, Foucault (1981) charted the massive increase in 
discourses on and about sexuality during that era. He argues that in bringing forth the body as an object of knowledge, 'sexuality' not only became the subject of discourse but also ever more closely subject to regulation. To name is therefore also to attempt to regulate. Foucault describes the notion of sexual represssion as an example of the broader 'repressive hypothesis', the view that power is always a constraint wielded by the powerful to limit or 'repress' the powerless. Foucault argues that power should instead be seen as an active, productive force that mobilises subjectivities and enacts subject positions. The exercise of power does nto Ismply enact victimhood, but also and at the same time evokes active subjectivities. This is a process that is empowering in the sense that it enables action, but it also serves as a means for the regulation of subjects. Here freedom is not the opposite of constraint. Freddom is possible in certain forms only because of the constraints and possibilities elicited through specific exercises of power. One cannot do away with the exercise of power, but one can change its geometries.

The notion of repression foregrounded by humanistic and therapeutic discourses therefore misconstrues this growth of regulation. Regulation is not constituted solely by repression, and the absence of overt regulation does not necessarily mean that repression is no longer present. To argue this way hides the work that practices of sexuality do in constituting and mobilising autonomous self-expressing subjects freed from overt constraints, yet who nonetheless remain regulated through regulating themselves. Action is not based upon autonomous agency, but on different geometries of power. All this is concealed In humansitic discourses, since one effect of the repressive hypothesis is that a particular view of sexuality is 'naturalised', or made an inherent characteristic of the embodied subject, thus concealing the effects of particular practices in framing particuklar manifestions of sexuality and the regulated body. 
In a Focucauldian view, people are positioned in a variety of subject positions, such as 'woman', 'man', 'child', 'parent', ‘teacher', 'learner', 'lover', 'clever', 'pushy', 'gay’. It is through this positioning by a network of multiple determinations that the affective and effective governing of people is secured (Rose 1999). To be a person is to occupy a subject position within a discourse, what Law (2001) refers to as a 'knowing location'. By talking about positioning we can see therefore that power can now be more resourcefully understood as relational, capillary and spatial, rather thans simply as a thing to be wielded by individuals and collectivities, such as the state. In problematising notions of 'essence' or 'human nature', as this does, we can argue that persons are not 'natural' givens in the world, nor is knowledge of them a process of discovering or uncovering their underlying reality. All is emergent. However, these notions precisely act as assumptions at the heart of humanistic notions that guidance enables individuals to authentically express their own true feelings, interests and circumstances. By contrast, Foucault (1981) argues that persons are rather framed through knowledgeable or expert discourses and normalising practices, such as humanistic psychology and their accompanying guidance and therapeutic practices. This knowledge and expertise is conditional upon, and a condition for, the exercise of particular forms of power, even as it is presented as a neutral process, or more accurately especially if it is presented as a neutral, 'scientific' process.

Discourses which bring to the fore the efficacy of guidance in eliciting one's self as an object of knowledge are therefore educational practices whose work is to constitute and make open for intervention those aspects of a person which have hitherto remained unspoken (Besley 2002). They are enacted through the relations and practices of confession rather than preceding those practices. To fabricate one's subjectivity as an 
object of knowledge is to discover the 'truth' about oneself where whoever guides this process plays an active and powerful role. In relation to sexuality, Foucault argued that the confessional practices of the Christian church were about the discursive transformation of desire in order that sex could be 'policed' rather than suppressed/repressed. Policing is regulatory rather than simply repressive. Regulation and governing displace oppression in the exercise of power, although the latter remains an ever-present possibilitiy. This process has spread and now encompasses not only sexuality but also education, health and lifestyle. It has become central in the governance of modern society, where externally imposed discipline has given way to the selfdiscipline of an autonomous subjectivity.

Thus, provocatively, Foucault (1981: 59) proclaims that 'Western man [sic] has become a confessing animal' . Here the purpose of confession shifts from one of salvation to that of self-regulation, self-improvement and self-development. In other words, confession actively mobilises a productive and autonomous subject, but one who is already governed and in this way there is no requirement for externally imposed discipline.

The confession has spread its effects far and wide. It plays a part in justice, medicine, education, family relationships, and love relations, in the most ordinary affairs of everyday life, and in the most solemn rites... One confesses in public and in private, to one's parents, one's educators, one's doctors, to those one loves...

(Foucault 1981: 59)

It is in the very process of confessing that people are enacted and enact themselves as speaking and desiring subjects, a knowing location. At the same time, they are entangled in exercises of power as they become subject to the authority and authoritative discourses of the partner (the confessor) within the transaction. The confessors include not only the 
priest but also the therapist, the counsellor and the educator, and, through for instance, interactive computer programmes and self-help books, this role can also take non-human forms. The confessional transaction generates material spoken by the confessing subject, a body of knowledge through which subjects are inscribed in particular ways.

These conceptual resources therefore enable us to see practices of guidance in education as forms of confession where the meanings ascribed to subjectivity and experience are already effects of pastoral power because of the confessional transaction involved. In order to participate successfully in confession, persons need to be confessing subjects. In other words, they are required to have already accepted or have been normalised to accept the legitimacy of confessional practices and the 'truth' of the particular meanings that these invoke. Thus, in guiding adult learners, there needs to be an acceptance on the part of learners that they are indeed learners, that they are positioned as a particular kind of learner, and as such are in need of learning for own their further development. A whole intellectual technology is mobilised in the attempt to stabilise such understandings of the self and guidance and associated educational practices (Edwards 2003).

Yet even as confession has become central to modern forms of governing, its status as a 'regime of truth', a particular power-knowledge formation, has been enacted as humanstic development and empowerment. In this sense, and in line with Foucault's general position, it could be argued that the most effective forms of power are those which precisely are not recognised as powerful. This is because they are either cloaked in the esoteric but 'objective' knowledge of expertise or because subjects internalise the humanistic discourse of helping and personal empowerment. Power-knowledge formations such as this intertwine expertise and personal empowerment, thereby 
displacing the need for active containment and overt oppression. In confessing, we are normed and become normal.

The obligation to confess is now relayed through so many different points, is so deeply ingrained in us, that we no longer perceive it as the effect of a power that constrains us; on the contrary, it seems to us that truth, lodged in our most secret nature, 'demands' only to surface; that if it fails to do so, this is because a constraint holds it in place, the violence of a power weighs it down, and it can finally be articulated only at the price of a kind of liberation. (Foucault 1981: 60) Thus, an active, autonomous and productive subjectivity is mobilised in confessional practices even as it remains a subject enacted through the power-knowledge formations that bring forth this form of subjectivity and invest it with significance (Rose 1998). It becomes 'natural' to confess, but what precisely are the forms of power at play?

\section{Power}

Foucault refers to the type of power exercised through confession as pastoral. This is an important component of contemporary governmentality, which Foucault (1979b: 20) defines as 'an ensemble formed by the institutions, procedures, analyses and reflections, the calculations and tactics, that allow the exercise of this very specific albeit complex form of power'. For Foucault, the notion of governmentality is a way of thinking power differently. In the discussion of the repressive hypothesis he argues that power should not be seen as 'thing like'; a repressive force wielded by some over others. The notion of governmentality points to the dispersed, networked capillary nature of power and its embodiment in rational forms of governing, administration, management and supervision, what Miller and Rose (1993: 83) term 'government at a distance'. 
In his work, Foucault distinguished analytically between pastoral and disciplinary power. Disciplinary power refers to those processes through which knowledge about the population is gained by government and where this knowledge functions as a condition for the effective management and governance of the people. These processes are embedded in the expert discourses of the human sciences, sciences that provide knowledge about, for instance, madness, deviancy, crime, and education. In modern social orders, disciplinary and pastoral power are in practice intertwined. In contemporary practices of governmentality these two forms of power-knowledge work interactively to bring into being individuals who actively and willingly (in the desiring sense of the term) participate in disciplinary regimes. They invest their own subjectivities and desires with those ascribed to them through the knowledgeable discourses of the disciplines. In this sense, the authority of confessional practices relies in part on the emergence of what Rose (1999) refers to as the 'psy' discipines, in particular psychology.

People are being encouraged to drive themselves ever harder, to accept even greater individual responsibility for themselves and their contributions to organisations and the social order. 'Choice' and 'development' govern the guidance process, yet the senses of autonomy and responsibility this enacts only engenders an even greater requirement for guidance as the stress of the apparent self-government engendered by confession serves to create its own problems. In other words, confession and pastoral power becomes selfreplicating, a self-sustaining dynamic creating the conditions for there own proliferation and endless iteration. Due to their basis in the process of confession and circulation of pastoral power, the very guidance processes through which people's difficulties are meant to be resolved actually result in further dislocation, as the sense of individual responsibility for one's condition, for the development of an autonomous and 
individualistic subjectivity and its accompanying stresses displace more social sensibilities. Thus, confession can be seen to play a central aspect in the individualisation characteristic of pastoral power in contemporary social orders.

For a long time, the individual was vouched for by the reference of others and the demonstration of his [sic] ties to the commonweal (family, allegiance, protection); then he was authenticated by the discourse of truth he was able or obliged to pronounce concerning himself. The truthful confession was inscribed at the heart of the procedures of individualisation by power. (Foucault 1981: 58-9).

It may be argued that this process of individualisation is a condition for the greater personal freedom experienced through the humane and emancipatory discourses of modernity. At one level, individualisation does provide the grounds for greater responsibility for self and enterprise as the limiting and constraining ties of kinship, community and tradition break down. This is a common enough argument. However, as we have seen, at another level, this can be seen more as the fashioning of a new form of subjectivity and a reconfiguration of the way in which power is exercised rather than its transcendence. In this sense, the very breakdown of alternative ties that bind is the result of the shaping and displacement engendered by pastoral power. The confessional practices of guidance have become a technology of governing and norming. The humanistic discourses of guidance which individualise learners are already part of an edifice of pastoral power, of a form of governmentality that itself needs to be problematised and addressed.

How then does this exercise of power take place? Foucault provides a suggestive argument for the work of confession. However, this is largely historical and textual, as his 
mutli-volume history of sexuality extended backwards into Ancient Greece from his initial exploration of the repressive hypothesis in the $19^{\text {th }}$ century. It also focuses on the qualities of the relationship of confession more than through a detailed empirical tracing of its practices. This then raises some interesting questions for those who want to research contemporary practices of confession and explore the extent to which this conceptualisation is still valid. Theoretically and methodologically, how might we explore the existence, nature and extent of confessional practices in current social orders? Here we believe actor-network theory has much to offer.

\section{The ANT-ics of confessing}

ANT is not a single unified theory, as it has developed and diverged over time. For Latour (1999a), it not simply a theory at all. We only draw slectively on ANT for this chapter. Furthermore, the relationship between actor-network theory and the work of Foucault is not a simple question to address. For Law (1992: 5):

Actor-Network theory is all about power - power as a concealed or misrepresented effect, rather than power as a set of causes. Here it is close to Foucault but it is not simply Foucauldian for, eschewing the synchronic, it tells empirical stories about processes of translation.

In other words, Law is suggesting that, while Foucault juxtasupposes aspects of the social order in suggestive ways, he does not provide detailed observational studies of contemporary practices. We want to argue that such observational studies are necessary in establishing whether or not the juxtapositions are justifiable or not and thus the nature and extent to which confession and pastoral power are conceptually sufficently to understanding aspects of social ordering today. 
To do this, we suggest that guidance practices can be seen as actor-networks where participants and participation are ordered in time and space and where there are configurations of the human and non-human in the confessing relationship of guidance. The confessing human subject is an effect of these orderings, not the point of origin. These networks 'expand, contract and shift configuration over time, and even the most stable and predictable of them are constantly being reappropriated and redefined by the nature of the flows that animate them...' (Nespor 1994: 12). They provide different possibilities for understanding and self-understanding, as 'left to their own devices human actions and words do not spread very far at all' (Law 1994: 24). Here the actions of subjects rely less on their own inherent capabilities and more on their relational character. To confess and what we confess is not simply a matter of humans emptying themselves as we would empty a bucket of water, but emerges from particular relational practices of the human and non-human that can be studied empirically. Thus 'all the attributes we normally ascribe to human beings, are generated in networks that pass through and ramify both within and beyond the body... an actor is also, always, a network' (Law 1992: 384). These can be traced observationally through what in ANT is referred to methodologically as following the actor.

In ANT, a network is constituted by the relationality of the different components, not by the actors themselves. To be an actor is not to be an origin of agency, but to be an effect of relationality through which action becomes possible. In other words, nothing acts in a vacuum but rather actors co-emerge with the relations that enact them. The subjects, in this case client and confessor, do not precede the relation through which they are enacted; they are an ector-network within which there are varius knowing 
locations. It follows therefore that actors are such precisely because they are in a networked relationship, bearing in mind that chairs, pens, desks, case notes are as much part of the action as any humans involved. Similarly, a client and confessor only exist within a confessional network of relations.

A network is always contingent, that is, it could be otherwise so it is in continual need of maintenance. Its reproduction can never be taken for granted; its configuration has to be worked at for it to hold together. Maintaining the stability of the network is vital and never ending, done through a process referred to as translation. This concept foregrounds the alignment of subjectivities, values and interests necessary to attain stability and order. Actors, both animate and inanimate, have diverse subjectivities, values and interests and these need to be interpreted, re-interpreted, represented and appropriated if they are to remain in a stable configuration. The spread of confession to which Foucault alludes is therefore a way of stabilising certain types of relationality as part of a wider ordering of the social.

Like Foucault, ANT does not constitute foundational subjects as isolated individuals or essential entities. Guidance can therefore be traced as practices that are not about penetrating deep-seated individualised meanings, getting to the 'core' of the self, but as ways of enacting the human as a confessing subject. By eschewing a psychologistic framework of explanation it does not privilege internal mentalistic processes. Instead the focus is on the material, on the mutual interaction of multiple intensities. All this has a significant bearing on how practices can be observed and understood. For ANT, these are not something that can exist separate from the context, but are rather dynamic activities distributed across knowers, the means of knowing and that which 
is known and across extended time frames and multiple resources. Guidance does not take place in a context, but is enacted and enacts certain relation as if they were background contexts, including the histories and specifics of the client. It can be traced as a knowledge-producing process where the knowledge produced is a special kind of talk, or to put it another way, knowledge is discoursed into being through the confessional transactions of the guidance encounter. However, without a perceived 'problem', there might not be a need for guidance at all. This problem tends to be defined in a particular and individualistic way through a humanistic discourse located in psychotherapy. With ANT, however, since a problem is not located within the individual but across the network, it is explored as a failure of translation that renders the network unstable, where instability is not always normatively a bad thing.

Supplementing Foucault, ANT suggests theoretically that confession is enacted in multiple and complex forms, which in research terms means that the empirical messiness should not be reduced simply to a totalised and totalising Foucauldian concept confession. By contrast, the latter could be expanded upon and developd further through observation and inference. What we are suggesting then is that the notion of confession could be developd further through more empirically focussed studies of its enactments. Here ethnography and ethnomethodology emerge as methods associated with ANT studies (Latour 1999b, Fox 2006, Fenwick et al 2011). These focus in depth on the specific practices through which translation is enacted in particular contexts, in this case the translation of guidance as forms of confession. We can say therefore that ANT presents a way of researching the relational rather than individualistic and that gives equal importance to the non-human as well as human in 
practices. This following of the process through which confession is enacted in guidance requires close observational study.

\section{Researching confession}

While ANT provides a methodological basis for empirically studying confessional practices, it is important to recognise that there are also differences. As we saw in the quote from Law above, ANT recognises its own debt to Foucault, or to put it another way, Foucault's work is itself an actor in the network that constitutes actor-network theory. Nonetheless the differences are there and we end this chapter by briefly pointing to our understanding of what these are. Law's argument here is instructive: What should we make of the difference between Foucault and ANT? If we say that objects are simply relational contingencies within ANT then it is primarily an empirical matter as to how they grow and how the relations producing them stabilise. This in turn means that in ANT the possibilities of the world are constrained but only contingently....[This] may be seen as a liberation from Foucault's dark obsession with the limits to the conditions of possibility. From his pre-occupation with the way in which we have been almost invisibly imprisoned for the last 200 years in the logics and strategies of the modern episteme. (Law 2000: 2)

What we understand by this is that whilst Foucault and ANT are both about power, how it is distributed and how it is mobilised and stabilised in ordering the social, Foucault seems to present a situation which argues for the inevitability of regulation. Only the forms of regulation change and, while Foucault also talks of resistance to regulation, this is not so richly and densely theorised. There is a sense therefore in 
which Foucault imprisons us in a gloomy iron cage of confession, discipline and pastoral power. Guidance and other forms of confessing, indeed any form of contemporary management of people's developmental trajectory, always ends up as regulation through self-regulation. The emphasis appears to be on the exercise of power as regulation, within limited room for transgression, despite Foucault's own evocations of the productivities of power.

With ANT however things could be otherwise. As Law argues in the quote above 'the possibilities of the world are constrained but only contingently'. When ANT argues that the constructing of networks is an empirical matter, this means that things are not as they are because that is how they have to be as a matter of inexorable confessional logic. An actor-network is regulative but how power works through the network is construed as much more flexible and subject to change than in Foucault's formulations of power. Networks are stabilised and mobilised by actors fabricating and negotiating common definitions and meanings and co-opting each other in their pursuit of knowledge-building. But at the same time networks can be dysfunctional, break down or be transformed. Stabilisation is for now.

Foucault is important in that he reminds us that the human(e) practices of guidance are not immune from the workings of power through confession. ANT, however, gives us more of a theoretical handle on the dynamics of guidance practices and the methods through which to explore them empirically. Both theorisations provide important resources for understanding guidance differently, while eschewing the desire to become the basis for an alternative technology of guidance. 
Guidance can be understood as the fabricating of confessional knowledge in action and interaction within settings where human and non-human actors are equally significant. It brings to our attention that knowledge enactment is a material process, within which there is the enacting and stabilising of the heterogeneous and the resistant. Confessional enactment is work, the mobilising of heterogeneous elements that require continual stabilising, precisely because of their resistance to such stabilisation. This is clearly a fruitful way of understanding what is happening in guidance practices. Guidance is translation work. The actor-network must be stabilised, interests and conflicts harmonised, if knowledge and self-knowledge is to be produced and if effective confession is to be enacted. Confession is a particular effect of particular actor-networks. This can be observed and traced.

In thinking guidance differently using resources provided by ANT we can begin to understand guidance as an ordered network of heterogeneous materials where resistanc and conflict has been overcome to different degrees of stability. The guidance interview, can be understood as a mobilised network of actors, where the network goes beyond those in the immediate dialogic encounter. Translations may include, for example, the school or college, parents and family, government agencies, the education system, psychotherapeutic theories to name but a few. Guidance may be considered a complex relational field of actor-networks where through translation participants and participation are more or less successfully choreographed, thereby constituting particular orderings of space and time through particular mediations. The strength of ANT therefore is that it reflexively provides a theory of relationality through which to re-imagine guidance practices as a socio-technical web of spatialised subjectivity- and knowledge-enacting practices. Thus, rather than the emphasis being on a 'learner' constructed psychologically, 
we can envisage an actor or subject who comes to know because they are located or positioned 'at the right place in a network of materially heterogeneous elements' (Law and Hetherington 2001: 3). Methodologically this entails some decisions about where to cut the network (Strathern 1996) in order to maintain a research focus, but answering that question also points to the centrality of the relational in social enactments, including those of confession.

\section{Bibliography}

Besley, T. (2002) Counselling Youth: Foucault, Power, and the Ethics of Subjectivity, Westport, Con: Praeger.

Ecclestone, K. and Hayes, D. (2009) The Dangerous Rise of Therapeutic Education, London: Routledge.

Edwards, R. (2003) 'Ordering subjects: actor-networks and intellectual technologies in lifelong learning', Studies in the Education of Adults, 35, 1: 54-67.

Edwards, R. and Usher, R. (1995) 'Confessing all? A 'postmodern guide' to the guidance and counselling of adult learners', Studies in the Education of Adults 27, 1.

Fenwick, T. and Edwards, R. (2010) Actor-network Theory in Education, London: Routeledge.

Fenwick, T., Edwards, R. and Sawchuk, P. (2011) Emerging Approaches to Educational Research: Tracing the Socio-material, London: Routledge.

Foucault, M. (1979a) Discipline and Punish: The Birth of the Prison, Harmondsworth: Penguin.

Foucault, M. (1979b) 'On Governmentality', Ideology and Consciousness 6: 5-22. 
Foucault.M. (1981) The History of Sexuality Volume One: An Introduction, Harmondsworth: Penguin Books.

Fox, S. (2006) 'Inquiries of every imaginable kind': ethnomethodology, practical action and the new socially situated learning theory', Sociological Review, 54, 3: 426-445 Latour, B. (1999a) 'On recalling ANT', in J. Law and J. Hassard (eds) Actor-network Theory and After, Oxford: Blackwell/The Sociological Review.

Latour, B. (1999b) Pandora's Hope, Cambridge: Cambridge University Press.

Law, J (1992) Notes on the theory of the Actor Network: Ordering, Strategy and Heterogeneity, Centre for Science Studies Occasional Paper: University of Lancaster http://www.comp.lancs.uk/sociology/soc054j1.html

Law, J. (1994) Organising Modernity, Oxford: Basil Blackwell.

Law, J (2000) Objects, Spaces and Others Centre for Science Studies Occasional Paper: University of Lancaster http://www.comp.lancs.ac.uk/sociology/papers/Law-Objects-Spaces-Others.pdf Law, J. (2001)'Ordering and obduracy', published by the Centre for Science Studies and the Department of Sociology, Lancaster University at http://www.comp.lancs.ac.uk/sociology/soc068jl.html (accessed 27 March 2003).

Law, J. and Hetherington, K. (2001) 'Materialities, spatialities, globalities', published by the Department of Sociology, Lancaster University at: http://www.comp.lancs.ac.uk/sociology/soc029j1.html (accessed 20 September 2001). Miller, P. and Rose, N. (1993) 'Governing Economic Life', in M.Gane and T.Johnson (eds) Foucault's New Domains, London: Routledge.

Nespor, J. (1994) Knowledge in Motion: Space, Time and Curriculum in Undergraduate Physics and Management, London: Falmer Press.

Rogers, C. (1961) On Becoming a Person, Boston: Houghton Mifflin. 
Roger, C. (1980) A Way of Being, Boston: Houghton Mifflin Company.

Rogers, C. 1983) Freedom to Learn for the 80s, Ohio: Charles E Merrill.

Rose, N. (1991) Governing the Soul: The Shaping of the Private Self, London: Routledge.

Rose, N. (1998) Inventing Ourselves, Cambridge: Policy Press.

Rose, N. (1999) Powers of Freedom, Cambridge: Cambridge University Press.

Strathern, M. (1996) 'Cutting the network', Journal of the Royal Anthroplogical Institute, 2, 3: 517-35.

Urry, J. (2000) Sociology Beyond Societies: Mobilities for the Twenty-first Century, London: Routledge.

Usher, R. and Edwards, R. (1998) 'Confessing all? A postmodern guide to the guidance and counselling of adult learners', in R. Edwards, R. Harrison and A. Tait (eds) Telling Tales: Perspectives on Guidance and Counselling in Learning, London: Routledge.

Usher, R. and Edwards, R. (2005) 'Subjects, networks and positions: thinking educational guidance differently', British Journal of Guidance and Counselling 33, 3 : $397-410$.

Usher, R. and Edwards, R. (2007) Lifelong Learning - Signs, Discourses, Practices, Springer.

Wright, K. (2010) The Rise of the Therapeutic Society: Psychological Knowledge and the Contradictions of Cultural Change, Washington: New Academia Publishing. 